\title{
古代ギリシャ・ローマ都市住宅における 上部空間に関する研究 \\ STUDIES ON THE UPPER FLOOR OF TOWN HOUSES \\ IN ANCIENT GREECE AND ROME
}

\author{
堀 賀 貴* \\ Yoshiki HORI
}

\begin{abstract}
The upper floor of town houses had a number of important functions, such as bedrooms, storerooms and dining rooms. This variety of functions is a characteristic shared by houses in both societies. An interesting distinction appears when method of construction is considered. Town houses in Greece were strongly affected by city planning that regulated that all rooms had to face south. On the other hand, town houses in lower and middle class housing in Pompeii show much less evidence of planning and an upper floor was often added at a later date.
\end{abstract}

Key Words: Greece, Rome, Pompei, Olynthos, town house, upper floor ギリシャ、ローマ、ポンペイ、オリュントス、都市住宅、上階

はじめに

古代ギリシャ・ローマ時代の住宅において、上階は常 に付属的な空間として扱われてきた1)。その結果、上階 は寝室、作業場、奴隷部屋、倉庫などの用途とされてい るものの、多くの場合、復原作業をともなう上部空間に ついては、依然として暧昧な点が多く残されている。 また、文献上にあらわれる古代ギリシャ住宅の多くに上 階の存在が確認できる一方で、オスティアに代表され る帝政期以降のローマ都市住宅におけるインスラと呼ば 扎る多層階の集合住宅が存在することも明らかである。 こうした、上階をもつ都市住宅の形式が、それぞれまっ たく戦独に発生し、展開したのか、あるいは深い関連性 をもつのかも大きな問題の一つであろう。

したがって、ポンペイに残る多くの住宅遗栦は、紀元 1 世紀以前の都市住宅を示しているという点で、非常に 重要な位置を占める。紀元前 1 世紀の建築家であるヴィ トルヴィウスは、建築夆の中で、特にギリシャ人住宅に
ついて記したが、それはギリシャ住宅が当時のローマ住 宅に深い影響を及ぼしたことを示すと同時に、逆に当時 のローマ住宅とギリシャ住宅が本質的に異質のもので あったことを示唆しているともいえる。ボエシウスは、 ローマ都市住宅の成立に関して、エトルリアに扑ける夕 ブリヌムとアラエの直交性がローマにおけるアトリウム 形式の起源となり、ギリシャからのペリストリウムがア トリウム式の住宅の後背部に付け足されて、ポンペイに みられる最も一般的な住宅形式であるドムス式が誕生し たと結論付けた2)。おそらく、ローマ住宅の起源がエ トルリアとギリシャ双方に遡るものであるということに 異諭はないであろう。しかし上階を含めてギリシャ住宅 からローマ住宅にすへてが完全に移入されたわけではな く、ローマ人はギリシャ住宅から何を学ひ、、何を切捨て たのかを明らかにする必要がある。

本諭においては、上記の観点を踏まえ、ヘレニステッ ク期から共和制後期にいたる、典型的口ーマ都市住宅が 
形成される時期に関して、特に上部空間の利用法に着目

し、考察を加えるものである。

また、特に保存状況之調查成果が充実している遗構で あるオリュントスとポンペイを中心に考察を進める3 。

I. ギリシャにおける上部空間

1. 文献に登場する上階

ギリシャ住宅における階上空間に関しては否定的な見 解が非常に多い。一般的には女部屋であるとか奴隷用の 部屋というような、いわば付属的なものであったという 見解が多いが、その理由は二階以上を示す実際の遗構が 全く現存してないこと4ににあると思われる。ロビンソン もオリュンソスの住宅群について「むしろ疑わしい」と 記している5)。

しかしながら、文献史料を調へてみると階上空間が必 ずしも付属的な機能しかもたされていなかったとは考え られない。上階の利用例としてはリシアスにおける、友 人を二階で接待した、あるいは食事をした、寝たという 記述6。アリストファネスにおいても二階にベッドがあ り、妻と奴隷が同室で寝たという記述がみられる7。一 階に男性用の寝室、二階に奴隷、妻の寝室という点で は、従来からの馓格な部屋の分離が強調されるが8)、部 屋の隔離についても、クセノフォンは「男性用と女性用 の区画の間に鍵を掛けた」と記し9)、男性用の空間と女 性用の空間が隣接していたことを示唆している。これ は、住宅のプランにおいて必ずしも男性用の部屋、ある いは女性用の部屋の配置が厳格に決められていたわけで はなく、部屋を男性用、女性用と使い分けることが重要 であったことを示している(10)。このように、アンドロ ン、アンドニーティスが男性用の部屋という明確な意味 があったとしても、それは男性用という部屋の機能に対 する呼び名であって、必ずしも住宅のある部分あるいは 特定の部屋を指し示すものではないと考えられる。

また、リシアス(I，9-10)に、エウフィレトスの家は従 来二階建で一階が男部屋、二階が女部屋であったか、子 供が湯を使う度に梯を登りおりするのが危険だという理 由で、男部屋と女部屋を入れ替えたという記事がある。

また、別の筒所では最も経済的な住宅として一階と二階 を同じ大きさにとったものが描かれている11。

これらの記述は、多くの部屋がその機能をお互いに入 机換えることが可能であったということを示唆してお り、アンドロニーティスなどの一部の部屋を除いて、お おくの部屋が特定の様式を要求せずに、類似した形態を 持っていたと考えられる。この点では、上記の文献上に 登場する住宅の平面構成が、パスタス式と呼ばれる、廊 下を介してすべての部屋が並列的に連結される形式で あったことを想起させる。文献史料は、ほとんどアテネ
に限定されるものであるため、アテネの住宅とオリュン トスなどの遗構が一致する確証は存在しないか、上階を 必ずしも付属的な用途として扱っていない参考例になる だろう。

\section{2. 上階の実際}

階上空間を実際に復原する試みも存在する。グラハム は、オリュントスの住宅群の中に階上空間を有する幾つ かの住宅を指摘しつつ、二階建が一般的に存在していた と結論付けているが122、その用途については明確にして いない。階上筀間を評価する上で、一つの判断材料とな るのが、二階に至る階段の配置である。なぜなら、二階 へどの部屋から登るかということを考察することによっ て、階上空間の性質が、ある程度推測できるからである 13)。オリュントスでは、階段の第一段に使われる特徵 的な石材が特定されており、階段の位置を決定すること ができるが、それによれば、階段には大きく分けて二つ の配置法がある。第一は中庭ないしその周辺の回粮部に 配置されている例（図 1）14)である。

この場合には、露天あるいは半外部の状態の可能性が 高く、天候に関係なく利用する部屋、例えば寝室や奴隷 部屋としては考えにくい15)。また、二階部分は、おそら く、アンフォラなどの重いものの貯蔵ではなく、菻など 湿気を嫌う軽量なものの貯蔵に利用されていたと考える のが妥当であり ${ }^{16)}$ 、生産活動の場であった中庭の補助 的な機能（㲑物倉庫や道具庫）が与えられていたと思わ れる。

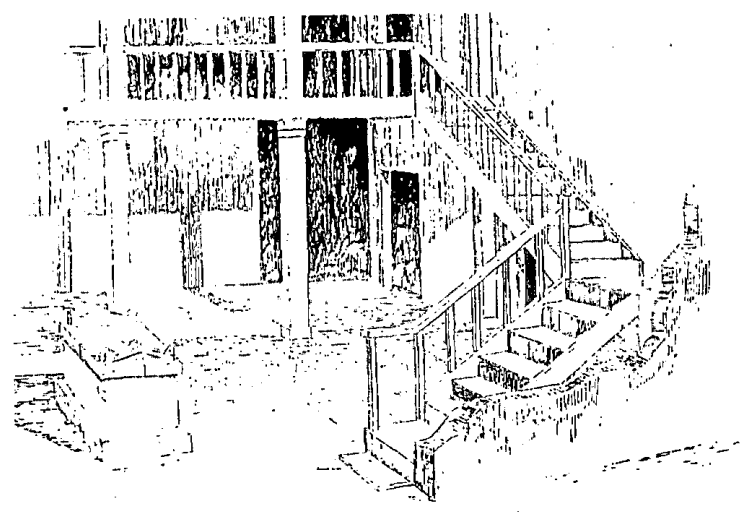

図1、オリュントスの住宅の中庭

第二にオリュントスには少数であるが、オイコス周辺 に配置される例がある。この場合、上階が第一の例のよ うに倉庫としてではなく、天候に関係なく利用する部屋 であった可能性が高い。しかも、オエクスから上階に通 じていたとすれば、二階は子供部屋か、正妻の寝室で あった可能性が高い17)。第二の例は、プリエネにおいて

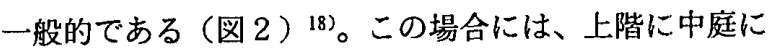


向かった廊下はなく、部屋は直接、中庭と面することに なり、一階と上階が必ずしも同じプランとはいえず、全 体の部屋数も少ない。

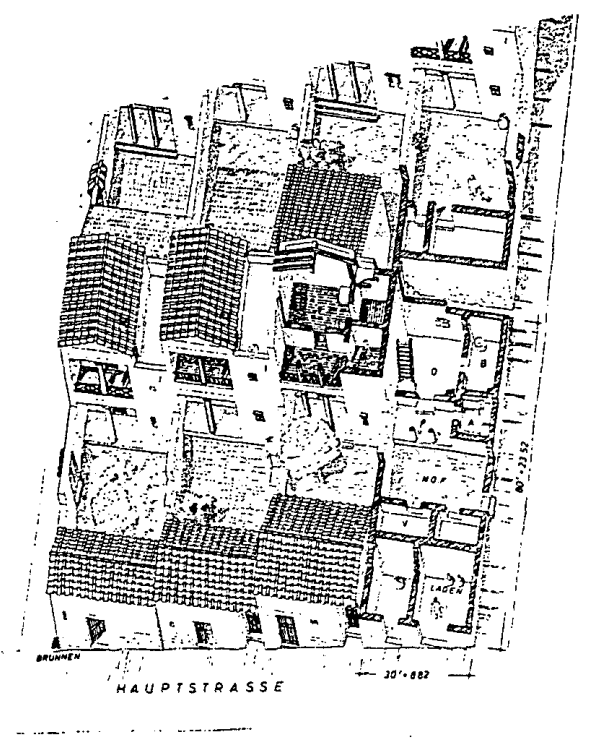

図2、プリエネの住宅

このように、上階にさまざまな使われ方が想定でき、 特に後者の場合、決して無視できない重要な機能を分担 していたと考えられる。しかし、すべてのギリシャ都市 で上階を持つ住宅が存在していたわけではなく、コロ フォンやカソッペなどの比較的簡素な構造しか持たない 住宅では上階は存在しない(19)。これらの、都市では、石 材も不整形で、壁の強度は上階を支えられるほどに達し ていないと思われる。また、敷地が格子状ではなく不整 形であるためオリュントスやプリエネのように採光や通 風に考虑しながら上階を建設することは非常に困難であ る。さらに、棈築法的に考えてみると、多くの都市で は、隣接する住宅が壁を共有しており、一体的に建設し なければ、上階の計画的利用は不可能であったと考えら れ、コロフォンなどの計画性の薄い都市ではその面から も上階の利用は困難であった。

このように、ギリシャ都市においては、上階は強い計 画性をもつ都市において発達し、用途別に使い分けがな されていたことが推定される。

\section{II. ポンペイ住宅の上部空間}

\section{1. ポンペイの都市住宅}

ポンペイにおいては（あるいはポンペイが初期ローマ住 宅を知るう上での最も有力な遺構なのだが）最も古い様 式を伝えているとされる「外科医の家」（紀元前 4 世 紀）は、遠く北イタリアのマルッァボットの住宅と共通 する部分の多いアトリウム式住宅の形式を持つ。また、
アルカイック期（紀元前 5 世紀頃）には、ギリシャの支 配下（具体的にはクマエやネアポリス）にあり、ギリ シャ神殿の建設や道路整備など、計画性の強い都市へと 変貌した ${ }^{20)}$ 。また、ポンペイはサムニウム時代やロー マ人占領後もギリシャ文明の移入の空口として栄え、ギ リシャの直接支配から脱した後も依然として強いギリ シャ文化の影響下にあったことは間違いがない21)。

エピディオ・ルーフォの家 (Casa di Epidio Rufo、紀 元前 3 世紀から 2 世紀）は、玄関広間はアトリウムとい うよりもペリストリウムに近く明確にギリシャ住宅の特 徵を示している。リチャードソンによれば、ペリストリ ウムを後背部に持つ住宅形式が確立したのは紀元前 1 世 紀頃と推定しているが22)、この時期の住宅であるノッ ツェ・アルジェントの家 (Casa delle Nozze d'Argento)、 メナンドロの家 (Casa del Menandro) カピテッリ・フィ グラーティの家 (Casa dei Capitelli Figurati ) などは典 型的なアトリウムーペリストリウム式の住宅、いわゆる ドムス式住宅の形態をとっている。これらはいずれも大 規模な住宅の部類に属するものである。従来のアトリウ 么型住宅形式に新しくギリシャ的な特徽を付け足したド ムス型住宅は、単純に考えれば従来の形式に比へて二倍 の面積を必要とする。紀元前 1 世紀以降ポンペイの人口

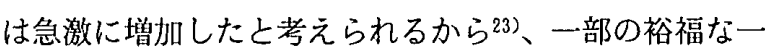
族を除いて、住宅建設について面積的な制約が加わった であろうことは容易に推测できる。

リングは、壁体構法の編年から、インスラの形成過程 を上記のメナンドロスの家を含むインスラ全体について 明らかにしている24)。これによると、やはり紀元前 1 世紀以降、ドムス式の住宅を建てるだけの空き地は残さ れていないといってよく、ドムス式住宅は他人の土地を 買収することのできる一部の裕福な一族に限定されて いったと考えられる。

さらにポンペイ全体で考えてみると、上記の古い形式 を持つ住宅がフォルムに近いいわゆる旧市街地区には少 なく、やや周辺の地区に点在していることも非常に興味 哚い。旧市街と呼ばれる地区では建築が密集し、完全な ドムス式住宅は数軒だけで、アトリウムとペリストリウ ムを持つもののペリストリウムを囲む柱廊が二方向だけ であったり、ペリストリウムではなくビリダリウムて あったりするのが実情であり、ほとんどの住宅はアトリ ウム式の住宅である。例えば後に詳述するレッジオ7、 インスラ12（以下VII，12 と記す）では、全体で21棟 の建築物があるが住宅専用のものは掞そらく4軒で、ド ムス式住宅は一軒もなく、唯一3の家のみが面積的にド 厶ス式住宅の可能性を持つ。さらに4軒の内、3の家以外 は二階部分が確認されており、面皘的に余裕のない住宅 においては、三階部分が住宅の一部として重要な役割を 果たしていた可能性がある。また、北侧の店舗の後背部 
にはアルコーヴ（壁が床から腰ぐらいの位置までくびれ たように凹になっている部分でベッドと考えられる）を 持つ部屋があり、住宅専用の建築物でなくとも、宿泊施 設を持つ事例もある。

このように、ポンペイにおいて、上階が確認される多 くの住宅はドムス形式を持たない中小規模の住宅であ る。したがって、上階を考察するにあたっては、従来あ まり注目されなかった中小規模住宅が中心とならざるを 得ない25)。

\section{2. 二階の有効な利用}

ワローは、ローマ住宅について以下のように記した。

「中庭（cavum aedium）を囲んで、（家は）それぞ れの目的に合わせて、壁で分けられる。(中略)上 階で食事をとるときには、家の上階の部屋は cenaculaと呼ばれ、」（De Lingua Latina, v, 162, ed. R.G.Kent (Loeb)、筆者訳)

彼の記述から以下の二点が読み取れる。第一は季節に よっては二階が食堂や居室などに使われていたと解积で きるか、この記述の対象は二䇢所に食堂を持つと思われ るかなり大規模な的宅であること。第二は冬に上階を利 用したことで、上階は一般的に冬に暖かく、夏には暑い と考えられ、ポンペイのような温暖な地方で恒常的に上 階を利用したかどうかは疑問が残る。しかし、二階を居 室として利用する習慣が存在したことは事実であり、必 ずしも、食堂以外の居室が上階に存在した可能性までが 否定されるわけではない。

そこで、以下に扔いて実際に実測調查を行う機会を得 たポンペイのVII，12の住宅群について上階の利用状況に 関して考察を加える。

1) VII, 12

VII，12の住宅群（図 3）に関して、注目すべきこと は、店舗あるいは生産施設を併設した住宅が非常に多い ことである26)。例えば、22の家は明らかに生産施設が中
心の家で、トリクリニウムやビリダリウムなどを持つも のの、その他の平面構成を考虑してみても、おそらくこ の家の持ち主は郊外か別の場所に家を持ち、この家に宿 泊することはなかったと考えるほうが妥当であろう。同 様に、北側の区画には規格化された店舗付き住宅が並ぶ が、住居としては非常に小規模のものであり、店舗が中 心の平面構成と言わざる得ない。22の家の場合之同様、 持ち主は別の場所に住んでいて、ここに寝泊まりするの は、別の管理者の可能性もあるだろう。ここでは、住居 を中心に検討しているので、詳述は避けるが、れらの 住宅群でも、二階部分が重要な役割を果たしていた可能 性がある。北側の店舗付き住宅群についてはほとんどの 家に上階への階段の痕跡が確認されているし、17，22 の 家にも生産施設と一体化する様な形式で二階が付設され ている場合が多い。

次に、主に居住用として使われていた 4 軒の内、上階 が確認される 3 軒について詳述する27?。

a.コルネリウス。ディアドィヌスの家

(Casa di Cornelius Diadumenus 、下図)

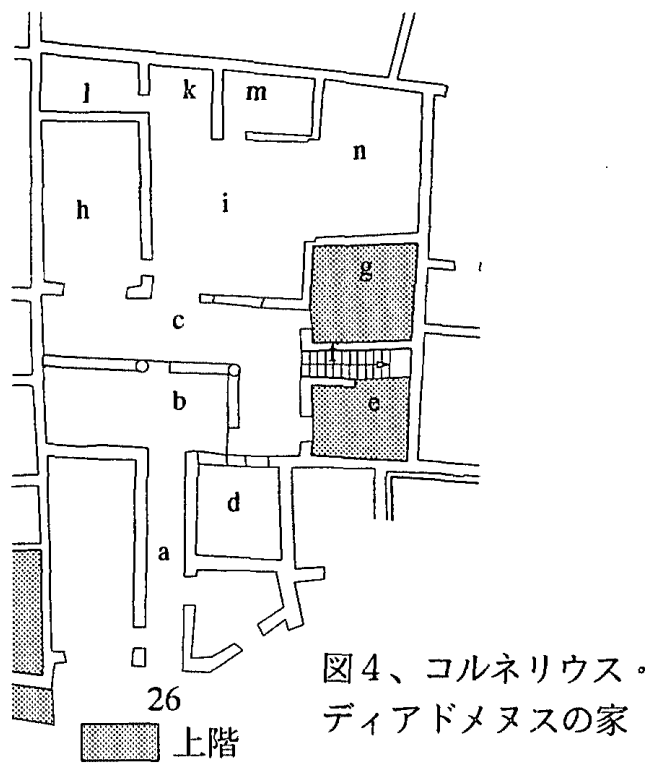

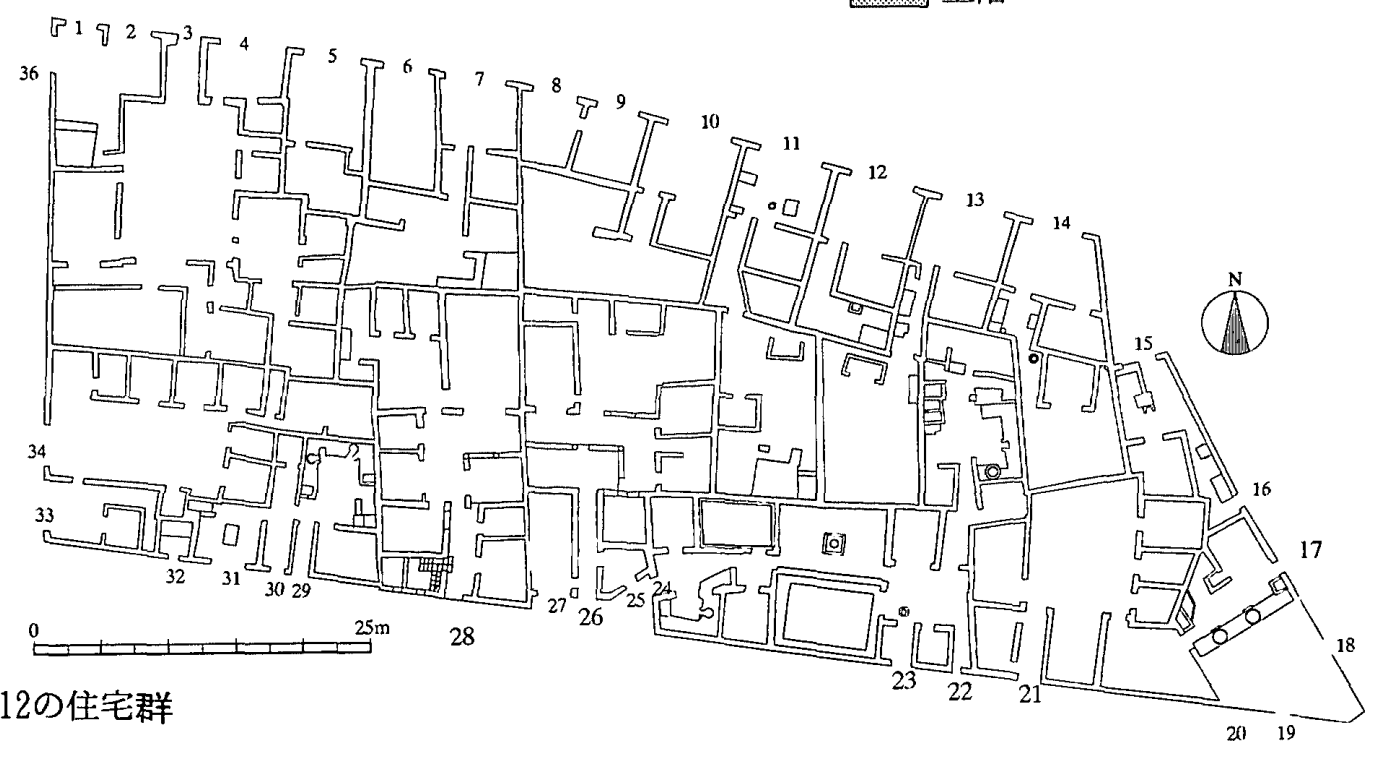


フィオレッリはd, e 室がク.ビクルム、hがトリクリニウ ム、iがアトリウム、kが夕ブリヌム、mがオエカスでn, g に関しては用途を記していない。彼は主に出土品や壁面 装飾を基準に用途を決定しているから、おそらく $\mathrm{n}, \mathrm{g} に$ いては手掛かりがなかったものと思われる。しかも彼の 記述では、奴隷用、主人用とも寝室が確定されていな い。iに関してはアトリウムと解しているが、完全ではな い。おそらく作業用のスペースであろうと思われる28)。

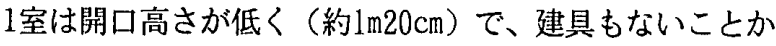
ら、物置のような付属的な部屋であったと考えられる。 $\mathrm{m}, \mathrm{n}$ 室は天井がヴォールト状になっていたと思われ、建具 も簡便なものが使用されていることから寝室とは考えに くい。またg室は、もとはi室に開口を持っていたが、c 室に変更され、両開きの屝が付いていることから寝室と は考えられず、倉庫か物置と考えられる。 ここでは二階部分がe, $\mathrm{g}, \mathrm{n}$ 室の上部に存在していたことが 推定される（図 4)。プランはほぼ一階と同じと考えて よいがおそらく、一階に馒室として適当な部屋が見あた らないため寝室の可能性が高い。この二階は、明らかに 増築されたものであり、もとはg室が漫室であったと推定 される29)。

b.バルコーネ・ペンシーレの家

(Casa del Balcone Pensile、下図)

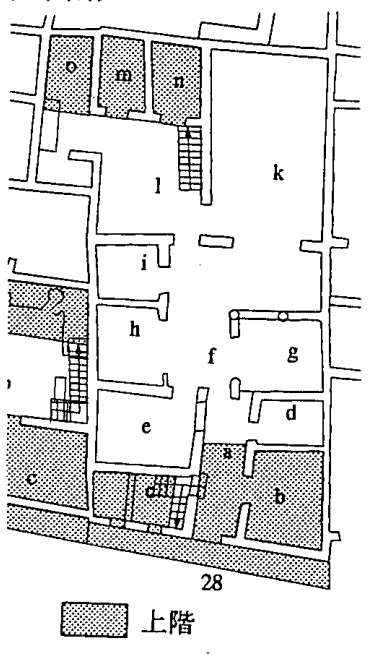

図 5 、バルコーネ ペンシーレの家 上階

フィオレッリの解釈では、bは共同寝室(おそらく奴隷 のためのもの)、d,iはクビクルム、eがトリクリニウム、 hがタブリヌム、kはエクセドラ、mは倉庫、nは眝蔵庫、 ○は台所となっている。おそらく、1室は作業場と考えて よい。他の部屋の用途は不明で、 $a, b, c, d$ 部屋の上部の 二階の用途についてもはっきりしない。このようなバル コニーのある家は、アボンダンツァ通りにおいて多く発 掘されているし、壁画のなかにも多く見られる30)。上 記のフィオレッリの解釈では、やはり主人の寝室が確定 されない。一階にあるのは奴隷用の寝室（薄暗く装飾も ないので彼は奴隷用と考えたのだろう）のみで、可能性 が残されているのは上階である。上階が確認されるのは 前面のバルコニーのある部屋と後背部のm, n, o室の上部 である。前面のバルコニーの部屋においては、装飾性は 豊かであるけれども、玄関らの部屋までに扉が一枚も存 在しないなど、アプローチの点から私的な用途は想定し にくく、商談などの接客スペースと考えるのが妥当であ る。したがって、主人の核室である可能性が最も高いの は、後背部のm, $n, o$ 室の上部と推定される。この部分 は、ブロックやレンガ積みが使用されており、比較的新 しい時期に上階も含めて、一体的に建設されたと考えら れる。一階の倉庫、貯蔵庫の天井高が非常に高く（約 4m）、二階の天井までの高は7m以上になると考えられ、 家全体の建設当時から計画されたとは考えにくく、この 二階をもつ部分のみが增築されたと思われる。 c.21の家（下図）

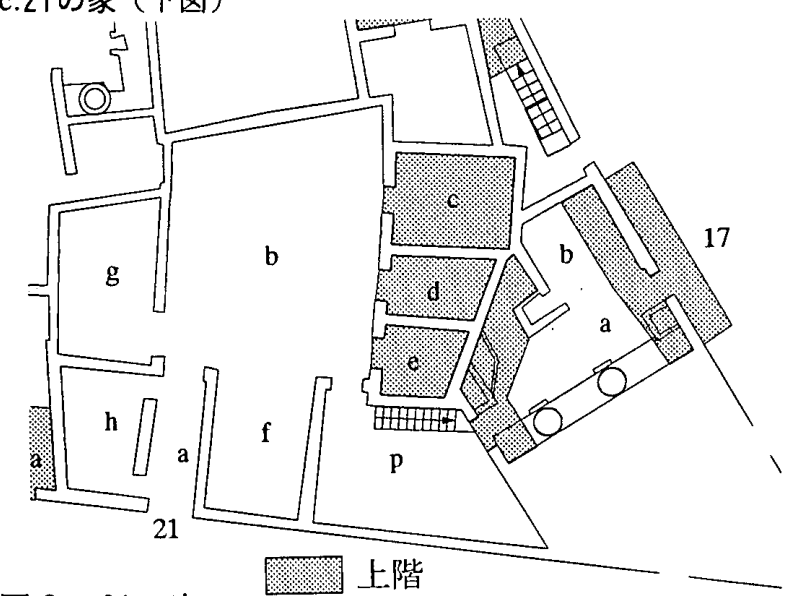

図 6、21の家

フィオレッリは、b室（アトリウム）やf室（食堂）な どの特徵的な部屋以外はすべてクビクルムと呼んでい る。21室の東側に並ぶ部屋はおそらく、装飾の豪華さか ら見て所有者の寝室である可能性が高い。この家は背後 で17の家と連結されており、17の家が生産設備（毛皮） 21の家が居住空間と思われる。二階にいたる階段の存在 がp室において確認でき、この部屋は明らかに屋根のな い外部である31)。この住宅で特筆すべきことは、住宅部 分の一階がアトリウム方向に開口を持つのに対し、二階 部分では17室側が開口となっている点である。二階部分 はわざわざp室の部分から回り込んでアプローチするこ とになる。出土物から判断して、二階部分も主要室とし

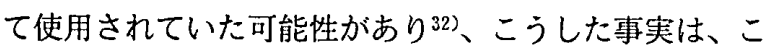
れら一階の部屋と二階の部屋の性格の違いを示してい る。二階への階段が住居である21の家と工房である17の 家の連結部にあることを考慮すれば、上階は居住用とい うよりも、隣りの住宅から工房を管理するための部屋の 存在が推定される。17の家の上階に注目するとa, d室全 体に二階の床が架かっていたという復原もあるが、構造 的に見て $\mathrm{a}, \mathrm{d}$ 室全体に床を架けることは不可能と考えて よい33)。またb室（倉庫）の上部はバルコニーを持ち、 非常に块適な部屋であったと思われる。したがって、二 
階の部屋が工房を見下ろすことのできる位置にあり、し かも工房からも隣りの住宅からも、比較的容易に昇れる 位置にあったことは、これらの部屋が商取引や接待など のある程度公的な役割を果たしていた可能性も十分に考 えられる。おそらく、管理的な立場の奴隷の寝室あるい は倉庫 (d, e, c 室の上部) とオフィスのような役割の部屋 （b室の上部、およびバルコニー）が並んでいたと想定さ れる。いずれにせよ、一階と上階で同じプランをもちな がら、開口方向がまったく逆であるという構造は、一体 的に建設されたとは考えにくく、やはり、平屋の住宅 か、工房の侀設に伴って、二階を增築したと考えるべき であろう。これらの住宅を考察してみると、ポンペイの この区画の住宅においては、上階が寝室に利用されてい る例が多く、26,28の家では主人の寝室である可能性が強 い。また、それらは”增筑”されたという性質が強く、 さらに上階を持つ住宅の多くは居住用の要請ではなく、 生産上のあるいは商業上の要請に基づいて建設（堌築） されたと考えられる。特に、26の家では寝室が別の用途 に転用され、二階に移動している。ポンペイの住宅では 食堂やタブリヌムなどの部屋はいずれも特徴的な形態を 備えており、他の用途への転用は困難であったと考えら れる。逆に寝室や物置など、クビクルムと呼ばれる部屋 が転用される機会が多かったとも考えられるだろう。

III.ギリシャにおける規格性とポンペイにおける特殊性 上階の利用法については上記の考察より、単純に上階 の用途だけを列挙してみると、奴隷の寝室、主人や妻の 垵室、倉庫などギリシャとローマではほとんど同じ用途 に用いられていると考えてよいけ机ども、その住宅平面 内で示す意味はまったく異なるといえる。以下でその点 について考察する。

1)発生過程での決定的な逗い

オリュントスやプリエネなどのギリシャ住宅は発生的 にみて、明らかに計画された住宅であり、建設当初から 上階の利用が想定されていたと考えてよい。

一方、ポンペイの住宅では街区は方形に近い状態であ るけれども、実際の住宅プランはいくつもの様式を経て 自然発生的に登場してきたものである。構法も必ずしも 一定せず、新しい構法が産まれても、以前の構法が消隇 するわけではなく、継続して共存した。したがって、当 初から上階の利用が計画されていた住宅は少なく、增築 という形をとった。

\section{2)二階の使用法}

ギリシャ住宅における計画的な性格は、オリュントス などの計画性の強い都市に限られ、文献史料とともに考 察してみると、アテネなどでは、他の計画都市で示され たような上階の利用は必ずしも行われていなかった。男
性用の寝室が必ず一階にあったことは、ギリシャ住宅と ポンペイ住宅の決定的な違いであるが、ポンペイにおい ては一階、二階を問わず主たる寝室の位置は確定されな い。

逆にいえば、部屋の用途を比較的に柔軟に変更できた ということは、各部屋が類似した形と中庭に面して集中 的に配置されているという平面構成を持ち合わせていた からであり、住宅平面における全体計画と規格の存在が 考えられる。

一方、ポンペイに执いては、二階の増築に対処療法的 かつ自然発生的な性格が反映されており、ギリシャの植 民都市のように画一的、計画的な上階の建設は行われな かったといってよいだろう。さらに、食堂やタブリヌム など特殊な形をもつ部屋が多いことから、部屋の用途変 更を柔軟に行うことは難しく、各部屋の用途はかなり固 定的であったと考えられる。

3)厳格な方向意識の存在

クセノフォンはギリシャ住宅について、以下のように記 している。

「家屋について、おなじ家が美しい家でありまた 有用な家であると語ることによって、家はどんな 風に建てるべきであるかを教えたように私には思 える。（中略）南向きの側を高く建てて冬の陽が さえぎられないようにし、北向きの側を低くして 寒い風があたらないように建てることが必要であ ろう。」(クセノフォーン、「ソークラテースの思い 出」、第三章、8節、佐々木 理訳、岩波畫店）

このように、ギリシャ住宅には明確な方向性があっ た。オリュントスの住宅のように、当初から南側を低く 北側を高くした住宅では、クセノフォンの教えに従う限 り、もはや二階の增築の余地はなかった。

この方向性は、ヴィトルヴィウスのシンメトリーの考 え方に通ずるものがあるが、彼の時代の住宅を実際に 眺めてみると、一部の豪華な住宅を除いて、シンメトリ 一は実現されていない。一方でオリュントスに見られる ように、ギリシャのいくつかの植民都市では、その方向 性が各住宅に確実に反映されている。特に、上階の建設 は採光や通風の点においても重要な問題であり、彼らは 住宅に画一的な平面を与えることによって、にとんどす へてての住宅でその問題は解決されているといってよい。 しかし、明確な方向性を持たなかったポンペイの住宅で は、場当たり的に上階が增築され、中小の住宅にはすで に共通性はあまり見られくなっている。その結果、採光 や通風の条件は必ずしも解決されていないといえる。

\section{結論}

このように、上階の機能を考察してみると、結果とし 
てギリシャにおいてもポンペイにおいても、上階に奴肈 室や倉庫、婦人の寝室など、従来の住宅史では注目され なかった従属的な部屋が配置されている。雨者で決定的 に異なる点は、ギリシャにおいて男性用の寝室が一階に 固定されていたのに対し、ポンペイの住宅においては、 主人の寝室でさえも上階に置かれている例が見られるこ とだろう。しかし、ギリシャ住宅においては、計画性と 方向性が優先され、いわゆる定型と呼ばれる住宅が存在 し、上階も同時に計画的に建設されていたと思われる一 方、ポンペイに打ける住宅は、上階は決して計画的に建 設されたものではなく、派生的に增築されたものであ り、その結果として、アトリウムやペリストリウムの周 りを各部屋が取り柬むという住宅形式すら守られていな い例が多数見られる。

ポンペイの都市住宅に関して、ペリストリウムなどの ギリシャ都市住宅の強い影響を容易に見いだすことがで きる反面、計画的都市を基盤に持つギリシャ住宅の上部 空間を含めた計画的な平面满成原理を見いだすことはて きない。ポンペイの住宅においては、一部の大規模な住 宅を除いては、ギリシャ住宅にみられる規範としての住 宅形式は存在せず、各住宅において個別に対応し、変化 していったと考えられる。

\section{謝辞}

本論は、（財）古代学協会の第二、三次ポンペイ調查に参 加して得られた資料に拠るところが大きい。現地において同協 会の方々のご指導、ご助言を頂いたことを記して、謝意にかえ たい。

註

1) ギリシャ住宅の砋に関しては、Lawrence, A. W.: Greek Architecture, pp. 238-249, 1973 ギリシャとローマ住宅の関連 については、Graham, J. W.: Origins and interrelations of the Greek house and the Roman house, Phoenix Vol.20, pp.3-31, 1966 ローマ住宅平面の研究は、Wallace-Hadwill, A.: The Social Structure of the Roman House, Papers of the British School at Rome, pp.43-97, 1988, Jung, F.: Gebaute Bilder, Antike Kunst 27, 1984 および、Drerup, H.: Bildraum und Realraum in der Rmischen Architektur, Rmische Mitteilungen 66,pp.147-174, 1959 など

2) Boëthius, A.: Golden House of Nero, pp. 18-25, 1960

3)これらの住宅平面が、それぞれ当時の一般的な住宅平面を 十分に反映していたことを前提条件として考察を進める。

4) Laurence, A. W.: op.cit., pp. 247 あるいは、Martin, R.: L'Urbanisine dans la GrceAntique, pp. 221-252, 1956

5) Robinson, D.M.: Excavations at Olynthus XII, p. 204,1946

6) Lysias : I . 22, ed. Gernet and Bizos (Bud)

7) Aristophanes, Thesm. 477-89, ed.. Coulon (Bud)

8）エヴァ・C・クールズ著、中訝梊郎、久保田忠利、下田立 行訳：ファロスの王国、岩波輩苫、pp. 242-248, 1989

9) Xenophon:Oeconomicus;9.3, ed. O.C.T. (E.C.Marchant)

10) Jameson, M.: Private Space and the Greek City, The Greek City, pp.171-19S, 1990

11) Lysias:1.9-10 およひ On the Murder of Eratosthenes,9, ed. Gernet and Bizos (Bud)

12) Graham, J. W.: Olynthiaka , Hesperia, XXII, pp.196-207, 1953

13)オリュントスについては、ロビンソンの復原を参照し、 それ以外の都市についてホフナーの復原を利用する。 Hoepfner, W., Schwandner, E. L.: Haus und Stadt im
Klassischen Griechenland, 1986

14) Robinson, D. M.: Excavations at Olynthus VIII The Hellenic House, p.217, 1938

15）中庭は生侜施没であったと考えられる。Walker, S.: Women and Housing in Classical Greece: The Archaeological Evidence, Images of Women in Antiquity, pp. 81-91, 1983

16） ヨーロッパや日本の民家の区別热く、作業空間に付随す る上部空間は軽量物の倉㡹となっている。Soeder, H. Urformen der abendlndischen Bukunst in Italien und dem Alpenraum, 1964

17)オエクスはいわばその住宅の主室（展間）であり、奴㩆が 常時自由に出入りする性質の部屋ではない。

18)プリエネはローマ時代まで存続した都市であるから、上陌 については多くの資料はないが、教地そのものが、念峻な 北上がりの地形をもち、二階の存在は、遗棈的な炋拠がな くとも予想できる。さらに、住宅のアゴラの通ずる朝線道 路に面し、紀元前 4 世紀にまで遡れるいくつかの住宅で は、階段が存在し、上階の存在が確認されている。ホーフ ナーはプリエネにおける最も一般的な住宅の帅式を提示し たが、階段の設置場所としてオイコスを設定している。彼 は一種の消去法によって階段の位置を特定した。すなわ ち、中庭や周辺の回榔に階段が無い以上（中庭やその周辺 に階段が在る場合には、水分による腐食を避けるため、必 ず階段不が存在するから）、階段は别の場所にあるという 推定である。さらに、敷地が南北に細長いことをその根拠 としている。いわゆるプロスタス式の住宅で、中庭に问， て回噱は設置されないので、中庭から上階に登ることは難 しいからである。

19) Holland, L. B.: Colophon, Hesperia XIII No.2, pp91- 171, 1944 および、Hoepfner, W., Schwander E. L., op.cit., pp.75-140

20) DeVos, A., De Vos, M.: Pompei Ercolano Stabia, pp.8-9, 1988

21) Ibid.

22) Richerdson, L.: Pompei An Architectural History, pp.324-29, 1988

23) De Vos A., De Vos M.: op.cit.; pp. 10, 1988

24) Ling, R.: The Insula of The Menander at Pompeii: Interim Report, Antiquaries Journal 63, pp.34-57, 1953

25）垝 賀貴：ポンペイにおける中・小規模住宅について、 日本建築学界近畿支部研究報告集, pp. 1029-32, 平成4 年度

26) Eschebach, H.: Pompeji, Leipzig, 1978

27）以下で用いる部屋記号と用途の解釈は、Fiorelli，G.: Gli Scavi di Pompei dal 1861 a 1872, Napoli, 1873 による。

28）調查洔に糸を紡ぐための素焼きの重りが確認されている。

29） 23 の家のk室の明り採り用の空がd室に付いていたものを c室に変更した痕があり、d, e室は野外であったものを室内 化しさらに、同時期あるいは別の時期に二谐化したもの之 考えられる。さらに、室は壁面の下層に壕華な装師が見ら れることから、もとは主人の寝室であったと考えられ、最 終的には寝室は二階に移動したと推定される。詳しくは、 Hori, Y.: The UPPER FLOOR IN REGIO VII INSULA 12 The Importance of The Upper Floor in the Study of Town Houses in Pompeii, Opuscula Pompeiana III, forthcoming.

30) Spinazzola, V.: Pompei alla luce degli ScaviNuovi di Via dell'Abbondanza, pp. 257-593, 1953

31）梁穴が確認できないことと、東南の隅に雨水の排水吅が 存在する。詳しくは、Hori, Y.: Thresholds in Pompeii, Opuscula Pomeiana II, pp. 73-91, 1992

32) Dwyer E. J.: Pompeian Domestic Sculpture, pp.53-56, 1982 に よると17の家には、二階から落下したと思われる不像が発 見されている。

33) Nishida, Y., Hori, Y.: The Investigaions of Regin VII Insula 12 , Opuscula Pompeiana II, pp. 48-56, 1992

圆版

図 1、Robinson, D. M. : Excavations at Olynthus VIII, Plate 73 よ $\eta$

国 2、Hoepfner W., Schwandner, E. L.: Haus und Stadt im Klassischen Grichenland, Abb. 172 より。

図 3〜6、段測データに基ついて、筆者が作図したもの。

（1993 年6月 10 日原稿受理，1993 年 12 月 10 日採用決定） 